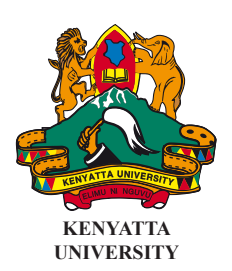

ISSN 1563-1028
CHEMCHEMI

International Journal of Humanities and Social Sciences

\title{
CONFLICTS OF LAND EXTENSION 'POLICY' IN LOGONE-AND-CHARI REGION OF CAMEROON (1953-2012)
}

\begin{abstract}
Ahmat Hessana
\section{Abstract}

From 1953, intra-ethnic violence erupted between qabbayil (Shuwa Arab ethnic groups), and between khashm buyut (clans and fractions) in Logone-and-Chari region of Cameroon. In that year, the breakup of the Sultanate of Goulfey led to the fragmentation of Shuwa Arab authority, then land extension 'policy'. In this study one also discovers that during Land extension in the Lake Chad basin, there was intra-ethnic violence. This paper evaluates the use of force between Shuwa Arabs from Logone-and-Chari when the need of new land supply targets the closest brother's lands. Recurring tensions, crises and threats are employed by the qabbayil about the kalankiat (ethnic land boundaries) and illegal villages. Between Shuwa Arab clans and fractions, violence refers to bloody confrontations and personal revenge. Up to 2012, these conflicts between ethnic groups and those within clans involved protagonist autochthonous policy, a land regulatory from Shuwa Arab economic elites and corruption from administrative Authorities. Those are the factors which block the process of stopping land violence between these Shuwa Arabs.
\end{abstract}

Keywords: Shuwa Arabs; Logone-and-Chari; Cameroon; Land Extension Policy; Violence, Recurrence.

\section{Introduction}

The borders area with Nigeria, Chad and Cameroon called Logone-and-Chari Division has had multidimensional conflicts (Saïbou Issa 2001, Fokou 2006). There are land conflicts and struggles for political hegemony (Kotoko/Shuwa Arabs, Kotoko/Musgum and Kanuri/Shuwa Arabs). Between these community groups, there are also tensions due to highway banditry. In addition to this list of inter-community conflicts in that region of Lake Chad basin, it should be noted that a new land issue assumes intra-ethnic groups proportions. In relation with the need of land resources, Shuwa Arab ethnic groups, clans and fractions ${ }^{1}$ behaviour from 1953 is a sign of intra-ethnic conflict over land (Figure 1). 


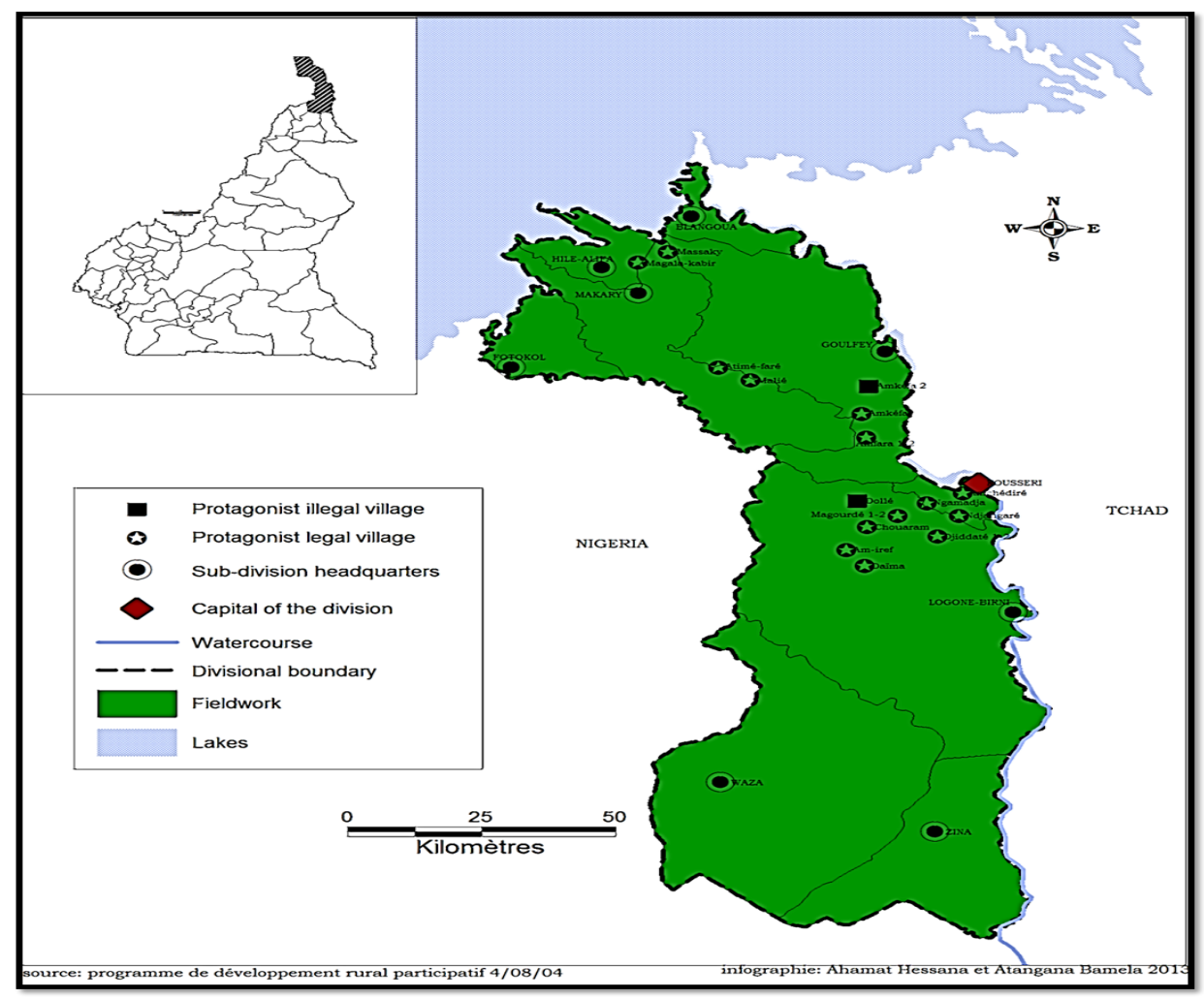

Figure 1: Locations of land conflict between Shuwa Arabs, Logone-and-Chari

In 1953, the Sultanate of Goulfey (North of Logone-and-Chari Colonial Region) was broken up into five self-governing Sultanates. By this decision, France granted power on taxes to the new autonomous Sultans. ${ }^{2}$ The enforcement of this reform reorganized the Shuwa Arab authority (Zeltner 1970, p. 181182). Before 1953, Lawanes, shuyukh and blama were the traditional rulers. ${ }^{3}$ From that time, their number increased. The struggles due to the new appointments of Shuwa Arab dignitaries brought fragmentation of the community's power. Newly political dignitaries came into conflict with the former. This situation involved tensions between tribes and clans (Hagenbucher 1973, p. 20). Many Shuwa Arabs migrants settled inside Logone-and-Chari. Their interest was to live far from their leaders in order to avoid the newly expensive taxes. But, when they founded villages in foreign lands, pre-established Shuwa Arabs described them as invaders. That is the beginning of the Shuwa Arab's Land extension policy (Ahmat, 2011).

Land extension policy is made by Shuwa Arabs from Logone-and-Chari region of Cameroon, either to extend the living space or to protect ancestral lands, against any neighbour's conquest. According to qabbayil and khashm buyut, Landownership over hellal (villages) and dirân (cattle camps) should not remain to the Kotoko Sultans. Since 1953 and above all in 1990s during the opening up to democratization, they forced way to self-reliance. To survey the area whose access to dwindled land supply is controlled by ethnicity (Saïbou, 2001) the qabbile or the khashimbeyt employ violence against each other. Because of this violence erupted between Shuwa Arabs from Logone-and-Chari region of Cameroon in order to achieve their land extension objectives.

\section{Land Extension Policy between qabbayil}

Lake Chad basin in general and particularly Logone-and-Chari Division is a specific region of frequent conflicts between Shuwa Arabs. Each qabbile is sharing sovereignty and greatness by reminding the others of her significant feature. For instance, Salamat are keeping up independence by carrying population weight as compared to Ghawalme, Bana Seyd, Hemmadiye and Essala. Close to Sultan of Goulfey ${ }^{4}$, Ghawalme are claiming that they are the mostly privileged ethnic group (Hagenbucher 1973). However, the sources of 'Shuwa Arab tribal Radius' (Ahmat, 2011, p. 84) seem to be considered as real manifestation of qabbayil's ethnicity actions. The analysis presented in this article focuses on ethnic land boundaries 
called kalankiat (sing. kalanki).

\section{Kalankiat: Unusual from the Beginning, Essential Nowadays}

Kalankiat refer to both materialized and theoretical boundaries between hellal and 'Shuwa Arab tribal Radius'. According to anthropologists (For example, Magnant, 1986, p. 272), these appear as ponds, trees and hillocks from eighteenth century to this day. Because qabbayil must not focus on, they got over without any dispute and confrontation. When Shuwa Arab ethnic groups and clans from the Sultanate of Goulfey experienced their land extension policy, they were followed closely behind by others in Logoneand-Chari. All of them called for new and right demarcation of their villages. They argued that invaders should not get over kalankiat if it's materialized. An 'ethnic bridge' was so built to secure cattle and other farming activities.

The 1953 qabbayil way of looking at kalankiat was directly related to Martiniello's 'ethnicity' theory'. By promoting their particular feature, Shuwa Arab ethnic groups adopted new strategies by challenging unusual boundaries until land extension granted. Clearly, they were expecting change from the then local borders to the theorized one. This fundamental focus of attention to kalankiat became geopolitical with high geo-economics stakes. Shuwa Arabs constantly needed new grounds for agriculture and pasture on which their housekeeping supply and cattle breed depended (Podlewski, 1964; Holl, 2003; and Fokou, 2006). For cooking, they harvested maize, sorghum, rice and picked darraba (a specific vegetable from Lake Chad), sorrel. For trade, new grazing lands were very important insofar as their increasing cattle produced much milk which was sold to meet other household needs. Qabbayil are highly regard kalankiat as sacred. Anybody who attempted to reduce their grazing lands was considered an enemy and would be resisted by force.

Owing to tensions around Ibou pond, relationship between Essala from Ndjagare and Salamat of Amchedire became strained in the 1950s. Good relations seemed to have been restored for some time but, tensions restarted in the 1980s. Amchedire 'Lawanate ${ }^{7 \text { ' }}$ strongly intended to settle in Ngamadja mainly among Salamat villagers. The Lawane were displeased with them because administratively, they chose to be tied to the Essala Cheikh Authority of Ndjagare. After the appointment of their first Essala Lawane, Amchedire's land policy was to gain land ownership inside Ndjagare's lands. Clearly, this policy went beyond designated kalankiat to try and capture the Al Farchaya Plain. However, in order to deter this, the Ndjagare went and occupied the plain first (Ahmat, 2011, p. 91-93).

The second example is from Makary Sub-division where Ghawalme from Malie ${ }^{8}$ and Salamat of AtimeFare were fighting for land resources around Ajouss pond. The first one claimed that six fields located around their grazing perimeter were cultivated by the second. Two other Salamat parcels of land created in 2000 in the same area beyond Ajouss led to Ghawalme's application for sending off. To date blama of Malie still protests against Atime-Fare's land extension policy. In his address to the Sub-divisional officer, it was absolutely clear that he wants Ajouss as boundary between villages. Although the cattle breeders from his village do not get access to the Ajouss water, Ghawalme's aim seem to be that of communal tenure (Ahmat, 2011. P. 93-95).

Essala and Salamat from Canton of El-Birke, Logone-Birni Sub-division have disputes about their tribal Radius theoretical boundaries. According to the Essala, the right boundaries are supposed to stretch from Al Badala pond towards the west between Houlouf and Magourde II villages to the Madaf pond. In the opposite, Salamat boundaries should be from Al Badala through Dibekrea and Moussahar large poud to Abounamir9 (Abdoulaye Moussa interview). In that green area of Lake Chad where woodcutters and charcoal dealers are still destroying bushes, Essala's intension was to singly manage the plentiful land resources around $\mathrm{Al}$ Badala extension. The Salamat were deeply against this.

These case studies show the qabbayils natural attitude for revising official decisions (Zeltner; 1970; Conte and Hagenbucher-Sacripanti, 1973) especially during land disputes. Looking at lands about which Shuwa Arab ethnic groups struggled, it also emerges that their leaders made a policy of 'talks without negotiations'. In fact, attacked ethnic group gave effect to the overrunning threats from the attacker. This 
qabbile initiated the crisis by launching her defence strategy.

Violence erupts on Shuwa Arab rural boundaries when one qabbile goes for another's lands by questioning their full right to ownership. When one qabbile from Logone-and-Chari region of Cameroon theoretically claimed boundaries, one notices that they decided on locations. Their land threats are violating not only natural ponds, trees and hillocks, but also encroaching on the neighbour's 'tribal land Radius'. These threats turned into tensions so that the protagonist qabbayil were permanently ready to react. The attacking side defined its target's territorial integrity (Michaud, 2004). Attacked tribe reacted in two different ways. Either they designed new kalankiat, or they clung to inherited natural boundaries. By these means, the ethnic groups tried to protect their land against invader's land extension objective.

\section{Illegal hellal Foundation: Crises and Threats}

Illegal hellal are Shuwa Arab villages in Logone-and-Chari Division which were created in violation of Cameroon's territorial Administration laws. Because of application of 1988, 16 February Circular Note $\mathrm{N}^{\circ} \# 00929 / \mathrm{LC} / \mathrm{MINAT/DOT/SOA} / \mathrm{BCT}$, foundation of villages is illegal in Cameroon. The ministerial circular read in part:

(Mon attention vient d'être attirée sur la tendance à multiplier les créations deschefferies traditionnelle de $3^{\text {e }}$ degré dans vos circonscriptions administrative respectives [...] Pour mettre fin à ces errements [...] j'ai l'honneur de vous demander: -[...] -d'arrêter jusqu'à nouvel ordre toute création de nouvelles chefferies) ${ }^{10}$

This circular addressed itself to six governors and their Divisional officers ${ }^{11}$. It warned them about the forbidden foundation of villages. The reason seems to be tensions and unrest which occur during and after foundation. This was a response to the failure to obey President Biya's decree in 1995, 2000 and 2010, through three other Circular Notes. ${ }^{12}$

Concerning village foundation in Logone-and-Chari Division, the majority of Shuwa Arabs ${ }^{\rrbracket}$ appear as the community mostly in great need. Due to their daily resettlement migrations in Lake Chad basin, access to new lands remains a necessity. This type of migrations first refers to Shuwa Arab's crossing from Chari eastern banks (now Chad) to western (Logone-and-Chari region and southern Borno State in Nigeria) in $15^{\text {th }}$ century. These migrations secondly indicate Chadian Arab's immigration in Logoneand-Chari at the beginning of European colonization. This also refers to resettlement in the same region of many Chadian refugees (Arabs mainly) during 1979-1982 civil war in their country (Zeltner, 1970, p. 124-139; Saïbou, 2001, p. 69). It is finally in Chari western banks that many Cameroonian Shuwa Arab migrants are looking for rich lands.

Considering the dynamics of Shuwa Arab's dependence on land, resettlement migrations are their guarantee for survival. The advent of Chadian Arab immigrants on Logone-and-Chari's lands may have had great demographic effect on Kousseri, Makary and Logone-Birni towns. As depicted in Table 2, the number of hellal increased per Sultanate or Sub-division. 
Table 2: Approximate Number of Hellal in Logone-and-Chari from 1958

\begin{tabular}{|c|c|c|c|c|c|c|c|c|c|c|}
\hline \multirow[b]{2}{*}{$\begin{array}{l}\text { Sub- } \\
\text { division }\end{array}$} & \multirow{2}{*}{\begin{tabular}{|l|}
$\begin{array}{c}\text { Sultanate } \\
\text { of } \\
\text { Kousseri }\end{array}$ \\
Kousseri \\
\end{tabular}} & \multicolumn{6}{|c|}{$\begin{array}{c}\text { Sultanate } \\
\text { of } \\
\text { Goulfey }\end{array}$} & \multicolumn{3}{|c|}{$\begin{array}{c}\text { Sultanate } \\
\text { of } \\
\text { Logone-Birni }\end{array}$} \\
\hline & & Makary & Goulfey & $\begin{array}{l}\text { Hile- } \\
\text { Alifa }\end{array}$ & Fotokol & Blangoua & Darak & $\begin{array}{l}\text { Logone- } \\
\text { Birni }\end{array}$ & Waza & Zina \\
\hline Year & & & & & & & & & & \\
\hline 1958 & 12 & 230 & 70 & 5 & 30 & 2 & 1 & 77 & 8 & 5 \\
\hline 1977 & 20 & 310 & 105 & 10 & 41 & 5 & 5 & 103 & 18 & 4 \\
\hline 2012 & 40 & 350 & 194 & 15 & 60 & 10 & 35 & 140 & 40 & 20 \\
\hline
\end{tabular}

Sources: Elingui and Tjeega (1978), Ahmat (2011)

Table 2 shows increasing evolution of hellal foundations in the ten Sub-divisions of Logone-and-Chari Division. Between 1958 and 1977 Zina Semites cattle breeders created 26 new villages in order to put in value Logone-Birni Sub-division's agro-pasture supplies (Fokou, 2006, p. 140). Figure 2 demonstrates, at the regional level, the increase of hellal foundations. From 440 in 1958, it soared to 625 nineteen years later, and to 910 in 2012.

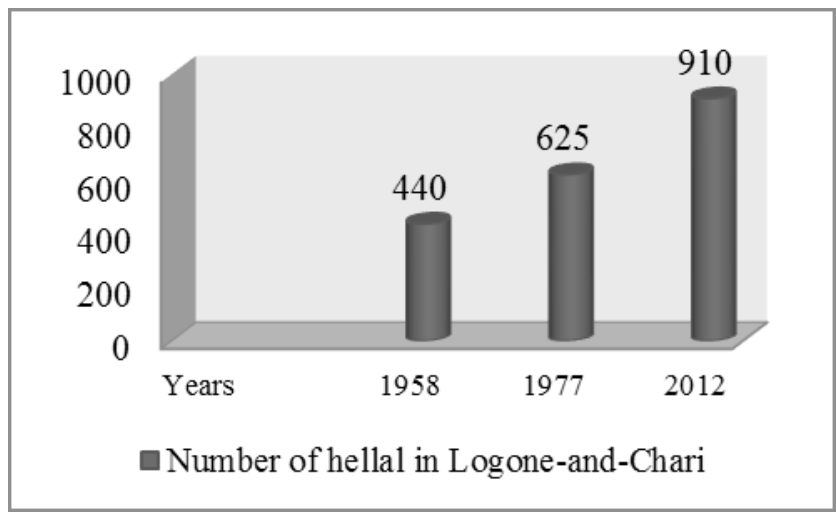

Figure 2: The increase of Hellal Foundations in Logone and Chari, 1958, 1977 and 2012

Numerous illegal hellal were created from 1977 to 2012. At the promulgation period of four circular notes listed above, foundations were confirmed by Logone-and-Chari Sub-divisional officers and political elites (Oumarou Housseïni and anonymous Shuwa Arab civil servant Interviews). In other words, although President Biya's ordered a stop to the foundations of third class chiefdoms, Shuwa Arabs carried on. Clearly, men who are affiliated to the same qabbile launched project of village's foundation inside another ethnic group's state property. They argued that administrative Authorities easily remained corrupted. Therefore, they relied on their rich economic elites until the Sub-divisional officers unofficially granted the foundations to them. ${ }^{14}$

Pre-established qabbile saw preliminaries invader acts of foundation under the way. As soon as they witnessed the first village's huts construction in their lands, migrants affiliated to the invader were called to settle. The crisis which started between the two qabbayil would reach its peak after the erection of huts. Once the full foundation of village was advised by economic elites, threats to battle took effect. These were violent stands about the foundation of hellal by Shuwa Arab ethnic groups. The foundation of Dolle's Salamat village in 2005 inside Essala's 'tribal land Radius' (canton of El Birke) is a significant case.

Since Salamat's settlement at Rabah area, there have been several rivalries between them and pre-established Essala. Harouna Younouss was a cattle trader from Wadjetouna whose father came from Salamat village and Djiddate II, and mother from Essala village. Because he was unwanted, he gained support from Logone-and-Chari Salamat economic elites. On 2005, 9 July, they allowed him to create Dolle village inside Essala's land cultivation. Essala members were anger by the settling of high numbers of migrants 
here. They demanded that the migrants be driven away. Owing to the support by Houlouf ${ }^{15}$ village, he refused to leave. Instead, he started to develop Dolle (Ahmat, 2011, p. 103-106). Investigations on the village's setting in September 2010 inventoried 25 huts and houses. What Harouna looked for, was the extension of grazing lands to his cattle. Nevertheless, an Essala coalition of blama decided to launch battle against Dolle's invaders. ${ }^{16}$ Between Shuwa Arabs from Logone-and-Chari region of Cameroon, there are not only qabbayils crises, threats and tensions, but also violence towards land extension that resulted to deaths and damage to property between clans and factions.

\section{Land Extension Policy among khashm buyut}

Regarding Shuwa Arab clans and factions, research shows that issues in Logone-and-Chari area are a matter of great concern (Conte and Hagenbucher-Sacripanti, 1973). Due to pressure on hellals population growth and land parcelling (Tientcheu, 2009, p. 129), they also promoted land extension policy. This led to bloody battles on the farmlands. For example, the 1950's initial cultivation of cereals in the Lake Chad basin had great effect on khashm buyut farmers (Seignobos and Iyébi-Mandjeck, 2002). To grant households adequate food supplies, they worked hard on their fields during the rainy season. They would work hard during the rainy season, but take a break during the dry spells. Taking account of these land opportunities, they considered their huts-and irrigated gardens as the best way to survive in Logoneand-Chari region. Their fundamental reason is that in this area, cattle breed is not more important than agriculture (Magnant, 1986; Fokou 2006). Maize, sorghum, millet, rice were introduced in 1953, a time when the Sultanate of Goulfey was also breaking up. Consequently, a land extension aim was initiated around farmer's lands. Among the khashm buyut, it became so violent in early 1960s and during the first decade of 2000.

First case study of bloody land battle goes back 1965. Two Salamat clans from Kousseri Sub-division (Am effan and Yesiye) were the protagonists. blama Grfeïna of Am effan Massilalkanam village grabbed parcel of land cultivated by one Yesiye farmer from Malah neighbour. As witness, Saleh (another Malah inhabitant) pounced on the invader. The two men knifed by one of their own. Reinforcements from two villages arrived at once on the battle field. They were spoiling for a definite fight. This attitude is indicative of Yesiye's annoyance after 1964 Chadian Am effan settlement on his agricultural perimeter.

Am Hato faction (Dar Begli Salamat clan) from Magala-Kabir village had their own cropland of beans which they developed in the western banks of Blemdague pond. In that zone, land property is still granted to Bekhite another Dar Begli faction. Their village Massaki located in Makary Sub-division is a long way off from Magala-Kabir in Darak Sub-division. They came in Blemdague lands then got off lines and finally destroyed Am Hato's beans (Ayia Mahamat Interview). According to Cameroon's sub-divisional Boundary plan of 2004 Darak's creation, the contentious area should revert to Massaki. Therefore, the Bekhite will not get access to it. To defuse crisis, Darak officer's order forbade any land activity. While Magala-Kabir farmers still carried on, young people from opposing groups staged a revenge leaving one dead, two casualties (on Bekhite's side) and three others (on Am Hato's one) (Ahmat, 2011, p. 117-119).

These examples demonstrate that khashm buyut's employment of violence undermined their integrity (Michaud, 2012). Use of knives and machetes became natural and useful reaction to achieve their land extension policy. Before battle, they underestimated deaths and casualties for land benefit. Even if their field boundaries always appear as lines of holes, fringed grasses and dry wall lands (Magnant, 1986, p. 273) they did not recognize them. However affiliated clan it may be, the main interest is to extend ancestral lands. The bloody violence employed by Shuwa Arab clans and factions around farmer's land is nearly close to this one which occurs about a type of lands being claimed as ancestral.

\section{Battle for Ancestral Lands}

There are lands that are under-and unexploited inside two or more hellal state properties in Cameroon area of Logone-and-Chari. The 1996 council elections results which led Shuwa Arabs in charge of six of the ten city councils have remained as a historic event. ${ }^{17}$ Instead of advantages thanks to the new political 
changes, certain Shuwa Arabs elites used to disturb peace in their own rural lands. They manipulated their clan brothers until unrest about lands described above occurred.

In details, khashm buyut summoned a link between those lands and ancestor up access. They scrambled under-and-unexploited stretches by claiming that these one were belong to ancestors. This is why one uses land extension policy phrase on lands claimed ancestral. Since early 1990s, this policy resulted in battle between Shuwa Arab clans and fractions. Battle found expression in political revenge. 1997 Amkefa's issue about underexploited patch of land seems to be illustrative:

(En 1997, un lopin de terre d'Amkéfa non loin d'Amfara est convoité par des Arabes Bana Seït venus du Tchad. Ils sont incités par Hissein $\mathrm{Ali}^{18}$ afin d'en venir prendre possession pour une raison [D’après] cette élite commerçante [...], ce site est celui de l'ancien village où vécurent leurs ascendants [...] La convoitise apparaît commanditée par Eli. Hissein Ali peut être considérée comme l' exécutant [...] Les querelles que livrent Eli, ses enfants et Hissein Ali à Mahamat Imar II et son grand-frère deviennent nourries lorsque les immigrants du Tchad parviennent dans l'arrondissement de Goulfey et font part de leurs intentions de s'installer sur le lopin d'Amkéfa. Le camp Mahamat Imar II repousse immédiatement cette initiative (Ahmat, 2011, p. 125-127).

Access to land fully granted in 1996 to Bana Seyd in Amfara 'Lawanate' (Goulfey Sub-division) is a threat to Hissein Ali's political objectives. He deeply wished to disturb land stability of Amkéfa population politically devoted to Prince Mahamat Imar II of Amfara (his challenger). As powerful member of Mahamat Abdoulkarim camp (one of the Shuwa Arabs lobbies from Logone-and-Chari) (Harouna, 2007), he caused land insecurity in his village Amkéfa and Amfara. In search of living space to his Chadian mother's family, he expected extension of his village lands inside Amfara's local land tenure. That tense situation led Mahamat Imar II side to be on alert. This one made the promise to wage his opponent. However, based on data collected on the fieldwork, one notes any casualties and damages. About unexploited lands claimed ancestral, battles resulted on serious bloody confrontations. Use of guns, knives and machetes brings out clear intention to kill. khashm buyut are engaged in. Following case hides a brutal land extension by two Salamat clans on goss Melloum Brahim.

Oulâd Fidde clan from Am-iref village wanted to carry off Melloum Brahim ancient landownership over a specific space which takes their ancestor name. Although one goss part gained by Oulâd Abu Jime from Daïma (the closest neighbours) thanks to Sultan Youssuf II (1914-1940) of Logone-Birni, they were attached to conquest full lands. After one meeting and reinforcements (nine villagers and mainly few affiliated traders come from Kousseri town), they attacked Daïma inhabitants on the goss area. Eight Oulâd Abu Jime violently resisted on 2010, $29^{\text {th }}$ March. Use of knifes, arrows, spears, assegais, staffs, and ammunition-tip gun involved two deaths, five casualties and five Am-iref's motorbikes damaged. ${ }^{19}$ (Abdoulaye Moussa and Mahamat Bahar Marouf Interviews)

Oulâd Fidde and Oulâd Abu Jime's clear intention to kill inside canton of El-Birke reveals Shuwa Arab emotional need forward land extension. By claiming free access to goss Melloum Brahim, their achievement is manipulation of ancient land privileges gained by the first clan migrants in that LogoneBirni Sub-division region of Cameroon. The upshot of qabbayil and khashm buyut employment of violence about their land against themselves is that Shuwa Arab economic elites are implicated. Another fundamental stand is protagonist autochthonous policy. The purpose of the next last part is to clarify those factors. 


\section{Outcome of Shuwa Arab Land Extension policy}

Land violence between qabbayil and between khashm buyut took other stands during the process of stopping. Traditional rulers and administrative Authorities are still sad to manage.

\section{Lawanes and Sultan's management}

As arbitrators, traditional rulers (Lawanes and Sultans) are for protagonist's reconciliation. To avoid new escalation of violence, they led numerous talks. But, their actions were thwarted by warring party's autochthonous policy. Belligerents insisted on absolute property on contentious lands, a restful if not positive solution. This weakened traditional managers who announced their withdrawal. At that time, Shuwa Arab tribes, clans and fractions launched other land extension projects.

About Ghawalme and Salamat's land extension policy around Ajouss, Sultan of Woulky was responsible of traditional solving. His actions to reconciliation of Malié and Atime-Fare blama failed. He told them that on the past, Ajouss pond has never been materialized as boundary. So, the six fields would not be regarded as contentious. Far from taking Ghawalme's side ${ }^{20}$, the decision he took, inflamed the tense situation. Malie smuggled its cattle in the contentious fields without official authorization. They strongly asserted that those fields were theirs. They refused to deprive of it. ${ }^{21}$

The Head of canton of El Birke also faced land autochthonous policy in Al Badala extension and Dolle illegal foundation cases. As legal arbitrator, he persuaded Essala brothers, Harouna Younouss and Salamat from Magourde II and Chouaram to take part to talks on his carpet. Salamat side harshly criticized him at the beginning because they think that he always supported his brother's tribe. At the end, they called his actions into question (Imar Djibrine and Abdoulaye Moussa interviews).

Salamat belligerent's dismissal of Chief Mahamat Abdoulaye is in line with Essala's renouncing affiliation to Salamat. Since 1890/91 Sultanate of Afade tribal war (Essala, Ghawalme, Hemmadiye and Bana Seyd coalition/ Salamat), Salamat of the whole Logone-and-Chari still remember their defeat. Furthermore, Essala split-up from Salamat tribe followed by name change from clan into full tribe in 1970s (Ahmat, 2011, p. 14) should remain the major highlights of the two Logone-and-Chari's Shuwa Arab tribes disagreements. Harouna Younouss and Salamat's rejection of Abdoulaye Moussa states as manifestation of this one.

In 2001, only Kotoko Sultan of Logone-Birni as superior of canton of El Birke ruler was accepted by Salamat belligerent ${ }^{22}$. This had made up by Shuwa Arab mind. Despite their free access to land since 1988, they strongly believed that Kotoko Sultans are the only traditional leaders who are able to confirm Shuwa Arabs as autochthons on any Logone-and-Chari's land stretch. In favour of management actions of the Logone-Birni ruler, those Salamat are still claiming full access duty to El-Birke land resources. According to them, Chief Abdoulaye Moussa is inexperienced because he was elected just since 1988 (Levy and Holl, 2002, p. 111). That is why he was not capable to decide without promoting Essala's land advantages.

Kotoko Sultan of Makary as arbitrator stepped in the bloody battle between Bekhite fraction and Am Hato. But, after first actions, protagonists required and obtained his withdrawal. Contrary to majority of Shuwa Arabs who went under Kotoko collection of land taxes, Landownership was fully granted at the colonial era to many Dar Begli from Hilé-Alifa, Makary and Darak Sub-divisions. Reinforcements they brought to French colonial conquerors against Rabah troops were deciding. France allowed them to keep land property that they gained after defeating Kotoko and Kanuri from Makary precolonial authority in eighteenth century (Zeltner, 1970; Hagenbucher, 1973). To two Dar Begli fraction's mind, dismissal of Sultan of Makary meant that their public image of Shuwa Arab conquerors and landowners in Chari and Lake Chad banks must be carrying on. Against kotoko first autochthons land policy in Logone-and-Chari region (Harouna, 2006), their land extension aim is fundamental for survival. So, taking part to talks under the leadership of Kotoko ruler of Makary should state as betrayal to their land conquest reputation inherited from Cheikh Wobri their famous ancestor (Zeltner, 1970, p. 180-184). In Logone-and-Chari zone where Shuwa Arabs definitively came to stop their public fear of Sultans and Lawanes (traditional main land managers), qabbayil and khashm buyut's land autochthonous policy challenged the famous Kotoko one. This can be explaining from 1988-1991 first election of Shuwa Arab second class Chiefs and 
Mayors at the head of vast land stretches. From 1996, these political changes due to democratization led to Shuwa Arab land access without any collection of Kotoko taxes. Because of monetization practice, these one are devoting to farmer and grazing lands extension rather than acquiescence to traditional managers. That is why in the end land extenders shifted the blame of management failure on their Lawanes and calling Sultans.

\section{Administrative Authority's action}

Independent Cameroon's land management by administrative Authorities is specified first in 1963, $9^{\text {th }}$ April presidential Decree on land tenure. As President, Mr. Ahmadou Ahidjo realized that this law weakened its power, strengthened and made rich traditional rulers. He signed 1974 Land Reform Act and 1977 Decree on chieftaincies (Ministère des Domaines et des Affaires foncières, 2007, p. 25). Kotoko Sultans from Logone-and-Chari Division were against although official application of these laws. From 1960 to 1988, Divisional and Sub-divisional officers could not impose their authority on land properties. But it was not the case through Gilbert Essala's order (Ahmat, 2011, p. 75).

To solve land issues between qabbayil and between khashm buyut, administrative Authority's action consisted in Shuwa Arab civil servant elites mediation. Those go-betweens became incredible in early 2000 s. Then, Divisional and Sub-divisional officers relied on Kousseri Islamic Council (KIC) actions from 1989. Cameroon's Advisory Commissions for solving land conflicts took decision based on civil servant elites and KIC's roles. Until 2012, these commissions only attached on Gendarmerie investigations and Kousseri Court of Justice (KCJ) sources.

Up to 2012, that deployment of administrative Authorities did not put an end to Shuwa Arab endogenous land extension policy. Credibility and confidence in civil servant elites objectively laid bare protagonist's responsibilities in land extension and used praise, credits as the better ways to stop violence. In authorizing mediation, head of Logone-and-Chari Division and Sub-divisions benefited much. On 1989, 16 ${ }^{\text {th }}$ June, they ended with Ndjagare /Amchedire extension aim on Al farchaya Plain. Joined actions coming from two belligerent's civil servant elites led to demarcation agreement according to which Ngamadja area should remain to Essala and the Plain to Salamat ${ }^{23}$. However, $1990 \mathrm{~s}$ numerous appointments of Shuwa Arab civil servant elites in Yaoundé city capital seem to be an economic elite's political reward decided by

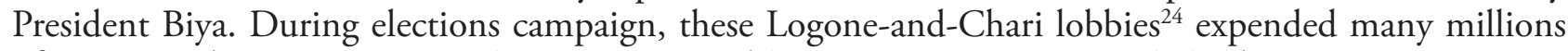
of CFAF to his Party CPDM (Cameroon People's Democratic Movement) (Saïbou, 2001; Harouna, 2006). But, from 2000, Adoum Gargoum /Kamsouloum Abbakabir ${ }^{25}$ political opposition (Guivanda, 2009) involved lobby's supremacy so that administrative Authorities are listening to trade elite's mind. At this stand, Shuwa Arab land violence management became lobby's business. Facing those civil servants elites, traders were still powerful. Until 2012, they appeared as the only land regulating force in fieldwork. However, the KIC also faced them.

The KIC was created in 1989 by Gilbert Essala Divisional officer in order to solve conflicts in Logoneand-Chari. Its purpose was to lead talks whose positive final agreement must involve belligerent's swearing on the Koran. This way in current application on Arab issues in Asia and North Africa (Magnant, 1986, p. 270) was highly useful to administrative Authority's action. In addition to Kotoko-Kanuri land system, KIC's objective was to abide by Muslim land law. faqarra ${ }^{\bigotimes}$ (sing. faqîr) honesty did not allow pacific solving because of their quite interest links to economic elites. This is the first sign of lobby's regulatory of land issues. One realizes at which stands the sacred character of Koran oath is removed by not only Shuwa Arabs from Lake Chad basin but also their glorious Muslim leaders.

About Salamat/Essala case study around Al Badala extension, the Imam who acted as KIC main member did not objectively lead the two legal Koran oaths on 2002, $7^{\text {th }}$ May. Instead of one, Salamat representative swore tree times meaning that their theoretical boundary is the right one. Better than the absence of Essala's swearing person, they remained unengaged. They refused this Imam as religious go-between at the end. The reasons were that he belongs to Salamat's tribe and he took the side one. He would be corrupted by Salamat economic elites who supported theirs (Ahmat, 2011, p. 134). Up to these analyzes, it clearly appears that qabbayil and khashm buyut's land extension actions were recurrent. Advisory Commission for solving land conflicts became immersed in. 
1974 Advisory Commission (in Land Reform Act) seems to be a powerless administrative formality on Shuwa Arab land violence file rather than majestic Authority. This one is under the leadership of Logone-and-Chari Divisional and Sub-divisional officers. There are Mayors, few traditional rulers, Police, Agriculture, Husbandry and land tenure divisional delegates as members (Ministère des Domaines et des Affaires foncières, 2007, p. 52). In Short, its action was to carry out member's inspections on contentious areas. After hearing again to traditional ruler's mind, administrative Authorities took drastic action.

When Kotoko Sultan of Logone-Birni traced the past of goss Melloum Brahim on Daïma/Am-iref bloody confrontation, of Dolle area and Sultan of Woulky did so on Ajouss pound, decisions were come from two Sub-divisional officers. Owing to the Kotoko autochthonous policy, those administrative Authorities trusted the Kotoko rulers according to which their ancestors granted land access to all Shuwa Arabs from Logone-and-Chari. Therefore, Kotoko customary chiefs are able to tell the truth about first settlement in contentious areas ${ }^{27}$. Due to Advisory Commission's believe in Kotoko rulers, protagonists who enjoyed dismissal of these one asked and gained lobby's support as revenge. In return, they made a deal of political alliance.

Lobby's political and land regulatory status became too powerful so that Divisional and Sub-divisional officers held out against. As witness belligerents and few civil servant elites, they would receive money from Shuwa Arab economic elites. Mr. Forna (2006-2010) of Darak Sub-division would be corrupted by two traders ${ }^{28}$ involved in Magala-Kabir/Massaki bloody battle. Mr. Oumarou Housseïni would do benefit thanks to Hissein Ali in Goulfey Sub-division. This is the reason why few lobby's appearing before Kousseri Court of Justice which was launched by administrative authorities (Ahmat, 2011) is still dangerous not only to Shuwa Arab land security but also to Logone-and-Chari's stability.

Twenty twelve's lobby's advent at CPDM central committee was destined to fail in solving of Shuwa Arabs land problems. This means that they assumed the right to aim any interest if there are mainly transfers of new administrative Authorities in Logone-and-Chari and new management strategies. Lobbies held now shuyukh and Lawane's old prestige, but also Kotoko Sultan's power on land. One can explain why administrative Authorities keep thinking that stopping qabbayil and khashm buyut's land extension policy is totally baffling (Abdoulaye Oumarou and Danna Haman Interviews). As one Shuwa Arab civil servant elite said: 'these land conflicts remain pending...to solve, belligerents have to wait'.

\section{Conclusions}

From 1953 to 2012, stands taken by land violence between Shuwa Arabs from Logone-and-Chari region of Cameroon were considerable. Crises, tensions and threats between qabbayil and khashm buyut's bloody confrontations are symptoms which put African autochthonous policy at the headlines of foreign socalled people's democratic demands. What it is true about land conflicts between qabbayil in Darfur region of Sudan (Ayoub, 2006) seems to be the same on Shuwa Arab ethnic group's land policy in Lake Chad Cameroon's banks.

In 1990s, Shuwa Arab autochthonous agenda towards land extension, economic elite's dominance on administrative Authorities, manipulation of Koran's oath and extents of damages were imbroglio in Logone-and-Chari. Due to the fact that Cameroon's Police and Gendarmerie shall maintain right order if there is an insecurity warning announced by international medias as RFI, BBC, France 24, land violence between Shuwa Arabs is not an emergency. After its Politics of Ethnicity on Kotoko/Shuwa Arab conflict (Saïbou, 2001), government has to focus on qabbayil and khashm buyut's land issues. Even if ways of solving followed official orders, it become clear that actions did not launch commonly and continuously. Traditional rulers, civil servant elites, Kousseri Islamic Committee faqarra's management took effect and followed by Divisional and Sub-divisional officer's detachment. From that administrative action without hard line, it emerges lobby's implication and land regulatory.

New procedures always involving all managers should be promoted by Ministers of territorial administration, land Tenure, State Property and Defence themselves. It will become efficient rather than several inspections on contentious fields. Meanwhile, civil servant elite's new mediation online in order to negotiate with lobbies should be standing by. 
The Shuwa Arabs are Semites from interbreeding of Arabs, Ethiopians, Fulani, and Black Sudanese. Instead of 'Arabs' like in Chad, they are called 'Shuwa Arabs' in Nigeria, Niger and Cameroon. 'Shuwa' is using first by Kanuris in order to qualify their good figure. Since fifteenth century, they are living in Cameroon, particularly in Logone-and-Chari Division. Five ethnic groups called qabbayil (sing. qabbile) make up their major highlights in Cameroon, namely: Salamat, Ghawalme, Bana Seyd, Hemmadiye and Essala. Each tribe has more than ten clans whom they called khashm buyut (sing. khashimbeyt). One clan is a combination of several fractions. In the Shuwa Arab society, one finds cattle breeders, traders, but also farmers and smaller fishermen. See Zeltner 1970, Hagenbucher 1973, Holl 2003 and Ahmat Hessana 2011.

2 From 1900, the Kotoko Sultan of Goulfey was the only ruler whom collected property taxes especially on Shuwa Arabs cattle and goods. In 1919, Vassal Sultans of Makary, Afade, Woulky and Bodo claimed landownership in their territories. More details see LCDOA (Logone-and-Chari Division Office Archives), Région du Logone et Chari, rapport annuel (I İre partie), 1953, p. 13-14.

3 In Rabah Empire (1893-1900) and Logone-and-Chari colonial Region (1900-1960), Lawane was at the head of each qabbile. shuyukh (sing. Cheikh) were clans rulers. But, they didn't have power over lands like blama in the villages. See Hagenbucher 1973.

$4 \quad$ He is the most powerful traditional leader in Logone-and-Chari.

5 'Shuwa Arab ethnic Radius' is a specific space which gathers together several Shuwa Arab villages inhabited by people related to one tribe or clan. Only occupants are putting in value these vast wide lands.

6 In Short, Martiniello's 'ethnicity' theory asserts that any ethnic group is taking up new attitude setting out demands from manipulation of common identities. See Martiniello (1995: 52) for more details

$7 \quad$ 'Lawanate' can refer to Shuwa Arab Lawane territory.

8 After the breakup of Goulfey, a Ghawalme settlement is allowed to create Malie village (in the Sultanate of Woulky) in 1953. Details in KCJA (Kousseri Court of Justice Archives) : Procès-verbal $\mathrm{n}^{\circ}$ $223 / 2008$ de renseignements judiciaires portant rébellion et incitation à la violence dans le litige foncier entre Malié et Atimé-Faré, 25 août 2008, p. 5.

9 KCJA, Correspondance du Sultan de Logone-Birni au Préfet du département du Logone-etChari, 15 octobre 2002.

10 Lettre Circulaire $\mathrm{n}^{\circ} \# 00929 / \mathrm{LC} / \mathrm{MINAT/DOT/SOA/BCT}$ du 16 févier 1988 interdisant la création de nouvelles chefferies traditionnelles au Cameroun, pp.1-2.

11 About ten provinces (now called Regions) in Cameroon, he listed Adamawa, West, North, North West, South -West and Far North where Logone-and-Chari Division is situated. He noticed foundation of many villages in these provinces.

12 Namely:

- Lettre Circulaire nº166/SG/PM du 17 mai 1995 confirmant les instructions présidentielles de sursoir aux nouvelles créations de chefferies traditionnelles ;

- Lettre Circulaire n02150/LC/MINAT du 13 septembre 2000 rappelant aux autorités administratives la prescription présidentielle du 17 mai 1995 ;

- Lettre Circulaire n00670/LC/MINATD/DOT du 9 mars 2010 insistant sur la prescription présidentielle du 17 mai 1995.

13 Opposite to the rest of Logone-and-Chari's community groups, their population weight in the fieldwork was $57.1 \%$ in $1953,64 \%$ in 1960 . It is over $75 \%$ in 2012. More details see Ahmat Hessana 2011: 79 . 
14 We will come back over Shuwa Arab economic elite's role at the third party.

15 Land tenure of canton of El-Birke was under the leadership of Kotoko Sultan of Houlouf from $15^{\text {th }}$ century to early 1890 . He lost it at Rabah period and then he got back (1900-1989).

16 KCJA, Correspondance des Chefs des villages Djidate I, Djidate II, Marafine I, Marafine II et Magourdé I au Préfet du département du Logone et Chari, 6 mai 2006.

17 Before elections, especially at President Ahidjo's era, Kotoko elites ruled all the city councils while their Sultans gained Landownership over Logone-and-Chari's lands (except Dar Begli's lands in HiléAlifa, Makary and Darak Sub-divisions). Saïbou Issa 2001 (good recommendation for more data)

18 Hissein Ali's mother would be their sister.

19 KCJA, Procès-verbal du Commissariat spécial du Logone-et-Chari relatif à l'affrontement Daïma - Am-iref, 2010.

20 They expected that Ajouss shall be and remain kalankiat between their village and Atime-Fare.

21 KCJA, Procès-verbal n006/PV/K23-02 de règlement de litige champêtre opposant le village Atimé-Faré à celui de Malié, 31 octobre 2007.

22 KCJA, Correspondance du Sultan de Logone-Birni au Préfet du département du Logone-etChari, 15 octobre 2002, p.1.

23 Kousseri Sub-division Archives (KSA), Procès-verbal de règlement du litige de limite de territoire entre les villages Amchédiré, Ibou d'un côté Djagaré, Komboula de l'autre et relatif à la détermination de deux pistes à bétail dans ces secteurs, 16 juin 1989.

24 From 1982, many Shuwa Arab traders still do huge profits thanks to Logone-and-Chari's vicinity to Chad and Nigeria. They are financing goods transactions from Cameroonian tows (Douala, Buea and Limbe) to neighbouring countries. More details see Saïbou Issa 2001.

25 Adoum Gargoum is acting as Minister Delegate in charge of Relations with the Islamic World and Dr Kamsouloum Abbakabir as Quester n ${ }^{\circ} 1$ in Cameron's National Assembly.

26 In Shuwa Arabs society, faqarra are Muslims who mastered Koran's sourates, and are Imams in the mosques. The most famous were KIC members.

27 LCDDLTSPA (Logone-and-Chari Divisional Delegation of Land Tenure and State Property Archives), Procès-verbal de règlement de litige foncier opposant la communauté salamat à celle d'Essala dans l'arrondissement de Logone-Birni, 29 juin 2005 ; Makary Sub-division Archives(MSA), Procèsverbal $n^{\circ} 1 \mathrm{du}$ règlement d'un litige agro-pastoral opposant le village Malié à celui d'Atimé-Faré, 6 juin 2006.

28 Ahmat Tom and Wobri Ramat 


\section{References}

Ahmat Hessana (2011) Les problèmes fonciers entre Arabes Choa du Logone et Chari au Cameroun(1953-2010). Master Thesis in History, University of Ngaoundéré.

Ayoub,M.(2006) "Land and Conflict in Sudan ", available at www.c-r.org our-work accord sudan Landconflict.php.htm. Accessed on 3 December 2011.

Conte, E. et Hagenbucher-Sacripanti, F. (1973) «Habitation et vie quotidienne chez les Arabes de la rive sud du Lac Tchad », Cahiers ORSTOM, n³, pp. 289-323.

Elingui, H. et Tjeega, P. (1978) « Dictionnaire des villages du Logone-et-Chari », Institut des sciences humaines $\mathrm{n}^{\circ} 17,127 \mathrm{p} .+\mathrm{XIV}$.

Encyclopédie Universalis (2012) «Violence », available at www.static.ak.fbcdn.net Accessed on 8 August 2012.

Fokou, G. (2006) Gestion communautaire des ressources naturelles et relations de pouvoir. Étude anthropologique des changements institutionnels dans les plaines du Logone et du Lac Tchad. Ph.D. Dissertation, University of Yaoundé I.

Guivanda, R. (2009) «Quand les barons nordistes se chamaillent », Eil du Sahel n³28 du11 mai, p.3.

Hagenbucher, F. (1973) «Les Arabes dits “Suwa” du Nord-Cameroun », Cahiers ORSTOM n¹43(série Sciences Humaines), pp. 1-38.

Harouna Barka (2007) Partis politiques et groupes de pression dans le Logone et Chari : 1944-2007. DEA Dissertation, University of Ngaoundéré.

Holl, A.F.C. (2003) Ethnoarchaelogy of Shuwa-Arab Settlements, Lanham: Lexington Books.

Lettre Circulaire n ${ }^{\circ}$ \#0929/LC/MINAT/DOT/SOA/BCT du 16 févier 1988 interdisant la création de nouvelles chefferies traditionnelles au Cameroun.

Levy, E.T. and Holl, A.F.C. (2002) « Migrations, Ethnogenesis, and Settlement Dynamics: Israelites in Iron Age Canaan and Shuwa-Arabs in Chad Basin, Journal of Anthropological Archaeology, 21, pp. 83-118.

Magnant, J.-P.(1986) " Les Arabes et la terre au sud du lac Tchad ", in Verdier, R. et Rochegude, A. (ed), Systèmes fonciers à la ville au village, Paris, L'Harmattan, pp.257-280.

Martiniello, M. (1995) L’ethnicité dans les sciences sociales, Paris, PUF, collection «Que Sais-je ?»

Michaud, Y., (2004) La violence, Paris, PUF, collection "Que Sais-je ?»

Ministère des Domaines et des Affaires foncières (2007) Régime foncier et domanial au Cameroun, Yaoundé.

Podlewski, A.M. (1964) La dynamique des principales populations du Nord-Cameroun (entre Bénoué et Lac Tchad), Paris, ORSTOM.

Saïbou Issa (2001), Conflits et problèmes de sécurité aux abords sud du Lac Tchad: Dimension historique (XVI-XXe siècles). Ph.D. Dissertation, University of Yaoundé I.

Seignobos C. et Iyébi-Mandjeck O. (2002) Atlas de la province de l'Extrême-Nord Cameroun, Paris, 
IRD et Yaoundé, Institut National de Cartographie, MINREST.

Tientcheu Njiako, A. (2009) Le titre foncier au Cameroun, Yaoundé, Arika.

Zeltner, J.-C. (1970) " Histoire des Arabes sur les rives du lac Tchad ", Annales de l'Université d'Abidjan, tome 2 (Série F), pp.110-236.

Zeltner, J.-C. (1988) Les pays du Tchad dans la tourmente, 1880-1903, Paris, L'Harmattan. 